\title{
GPR15 Gene
}

National Cancer Institute

\section{Source}

National Cancer Institute. GPR15 Gene. NCI Thesaurus. Code C140245.

This gene plays a role in T-cell homing. 